\title{
COMPARATIVE ASSESSMENT OF THE CHEMICAL AND ADSORPTIVE CHARACTERISTICS OF LEACHATES FROM A MUNICIPAL AND AN INDUSTRIAL LANDFILL
}

\author{
EDWARD H. SMITH \\ Department of Civil and Mechanical Engineering, Southern Methodist University, \\ Dallas, TX 75275-0335, U.S.A. \\ and \\ WALTER J. WEBER, JR. \\ Environmental and Water Resources Engineering, Department of Civil Engineering, \\ The University of Michigan, Ann Arbor, MI, U.S.A.
}

(Received April 23, 1990; revised October 8, 1990)

\begin{abstract}
Leachates from two landfills, one municipal and one industrial, were compared with respect to their chemical and adsorptive characteristics. Concentrations of most inorganic constituents were as much as an order of magnitude higher for the industrial leachate. The concentration of organic matter in that leachate, measured as total organic carbon (TOC), was more than two orders of magnitude greater than that of the municipal leachate. Gel permeation studies suggested similar molecular weight distributions for the organic fractions of the two leachates, but specific priority pollutants identified were different. The adsorptive characteristics of the waste samples with respect to activated carbon were evaluated using TOC as a lumped parameter expression of organic matter concentration. Adsorption equilibria and rates for the municipal leachate system were reasonably well described by treating TOC as a single component for modeling purposes. The industrial leachate required a multicomponent approach. Ideal adsorbed solution theory was used in this case to characterize the behavior of a set of hypothetical TOC components. The approach was able to account, to some degree, for the competitive interactions evident among organic solutes comprising the mixture.
\end{abstract}

\section{Introduction}

Proper management of landfill leachates poses a unique enviromental challenge in view of the complexity, site-to-site variability, and potentially hazardous nature of their chemical constituents. The complexity of a leachate is especially evident in its organic composition, which may include a host of synthetic organic pollutants, free volatile acids, humic and fulvic substances, and degradation byproducts. The organic composition may vary greatly from site-to-site, depending upon factors such as types of wastes deposited, method of filling, ambient conditions, and the age of the fill (Peavy et al., 1985; Gourdon et al., 1989). The ability to characterize landfill leachates is of obvious importance, so that appropriate treatment and disposal measures can be implemented to alleviate the adverse impacts of hazardous substances that may be present.

By virtue of its proven ability to remove a wide variety of organic substances, adsorption by activated $\mathrm{C}$ is a potential treatment option for leachate organics. 
Adsorption may be applied either as a polishing step following biological stabilization of high-strength leachates, or as a sole means for reducing the organic content of low-strength wastes. Because precise characterization of complex mixtures such as leachates is difficult, the development of reliable and consistent parametric means for monitoring and modeling the performance of adsorption processes in this application is a particular challenge. To date, the most promising approaches to adsorption modeling have merged fundamentals derived from well-defined systems of one or two specific organic compounds with lumped-parameter concepts that simplify otherwise complex and relatively uncharacterized organic matrices (Fettig and Sontheimer, 1987a, b; Weber and Smith, 1987).

This paper address several of the above considerations by: (1) presenting and comparing the chemical composition of a municipal and an industrial landfill leachate; (2) comparing and describing the adsorptive characteristics of the organic matter in the two leachates when treated with activated $\mathrm{C}$; and, (3) examining the utility of several modeling approaches for simulating the adsorptive behavior of leachate organics utilizing lumped, surrogate parameter representations.

\section{Experimental}

The municipal landfill leachate was collected from a drain sump of a solid waste cell at the Ann Arbor, Michigan city landfill. The industrial landfill leachate was obtained from the collection drain of a hazardous waste cell at Wayne Disposal, Rawsonville, Michigan, located approximately twelve miles east of the municipal landfill site. Both cells were in operation for less than $3 \mathrm{yr}$ at the time of collection. Leachate samples were prefiltered using a prewashed Whatman 934 AH glass fiber filter to remove larger suspended particles that might interfere with analyses and with adsorption experiments.

Inorganic analyses were performed according to Standard Methods (1980). Total organic carbon (TOC) was measured using a Dohrman DC-80 total organic carbon analyzer. Identification and approximate concentrations of priority organic pollutants were determined in volatile fractions and base neutral and acid extracts using gas chromatography-mass spectroscopy (GCMS) analysis (Hewlett-Packard GCMS instrument). The extracts were prepared according to EPA methods 624 and 625 (EPA Test Methods, 1982).

Molecular weight estimates were obtained by gel permeation chromatography. Samples were concentrated using a Buchi Rotavapor R110, and then injected into Sephadex G-50 and G-100 columns, 1.6 by $40 \mathrm{~cm}$. The mobile phase was $0.025 \mathrm{M}$ $\mathrm{Na}_{2} \mathrm{~B}_{4} \mathrm{O}_{7} \times 10 \mathrm{H}_{2} \mathrm{O}$ solution at $\mathrm{pH}$, which was membrane filtered and degassed prior to use. Four proteins of known molecular weight were used to calibrate the columns before injecting the samples. Concentration losses as given by TOC measurements were approximately $8 \%$ for the municipal leachate, and between 3 and $8 \%$ for the industrial leachate.

The solid phase used in all adsorption studies was Filtrasorb 400 (F-400, Calgon 
Corp.) activated $\mathrm{C}$ having a surface area of $\sim 1000 \mathrm{~m}^{2} \mathrm{~g}^{-1}$. Adsorption isotherm experiments were conducted at $22 \pm 2{ }^{\circ} \mathrm{C}$ in multiple completely mixed batch reactors (CMBRs); specifically, in this case, $160-\mathrm{mL}$ glass vial reactors. Varying amounts of $\mathrm{C}$ in powdered form were placed in a series of these reactors, followed by contact with leachate solution diluted to a known initial TOC concentration with deionizeddistilled water. All solutions were buffered to $\mathrm{pH} 6.5 \pm 0.2$ with phosphate. After a 5-day contact period during which the reactors were completely mixed, a sample was taken from each, filtered to separate the $\mathrm{C}$ using a prewashed glass fiber filter, and analyzed for residual liquid-phase TOC concentration. The solid-phase concentration was then calculated by mass balance, using a set of control samples (i.e., without $\mathrm{C}$ ), to establish the actual initial liquid-phase concentration. Control and blank samples were filtered and analyzed in the same fashion as the test samples, with the blanks having residual TOC concentrations consistent with that of the deionized distilled water used which was on the order of $0.1 \mathrm{mg} \mathrm{L}^{-1}$.

Adsorption rate experiments were performed using a 2.3-L CMBR and 30/40 U.S. standard sieve size granular activated $C$ (average particle radius $=0.026 \mathrm{~cm}$ ). At the beginning of each rate experiment $(t=0)$, a predetermined amount of $C$ was added to a stirred reactor containing leachate. Several milliliters of sample were withdrawn at each of a number of subsequent recorded time intervals, filtered to remove $\mathrm{C}$ fines, and analyzed for TOC.

\section{Results and Discussion}

\section{ChemiCAL CHARACTERISTICS}

The raw municipal and industrial leachates have the general chemical characteristics given in Tables I and II, respectively. The inorganic parameter values in Table I are of the same order of magnitude as has been reported in other studies of landfill leachates (e.g., Gourdon et al., 1989). The industrial leachate is obviously a higher strength waste by comparison. Of particular interest to this study is the

TABLE I

Chemical composition of the municipal landfill leachate

\begin{tabular}{lcll}
\hline $\mathrm{pH}$ & 7.8 & & \\
Alkalinity & 960 & $\mathrm{mg} \mathrm{L}^{-1}$ & as $\mathrm{CaCO}_{3}$ \\
Total hardness & 680 & $\mathrm{mg} \mathrm{L}^{-1}$ & as $\mathrm{CaCO}_{3}$ \\
$\mathrm{Ca}^{2+}$ & 120 & $\mathrm{mg} \mathrm{L}^{-1}$ & \\
$\mathrm{Mg}^{2+}$ & 92 & $\mathrm{mg} \mathrm{L}^{-1}$ & \\
TOC & 58 & $\mathrm{mg} \mathrm{L}^{-1}$ \\
Specific organic compound analysis & & \\
$\quad$ Diethylphthalate & 2250 & $\mu \mathrm{g} \mathrm{L}^{-1}$ \\
$\quad$ Other phthalates & $50-450 \mu \mathrm{g} \mathrm{L}^{-1}$ \\
$\quad$ Hexanedioic acid & 250 & $\mu \mathrm{g} \mathrm{L}^{-1}$ \\
$\quad$ Benzenedicarboxylic acid & 3750 & $\mu \mathrm{g} \mathrm{L}^{-1}$ \\
\hline
\end{tabular}


TABLE II

Chemical composition of the industrial landfill leachate

\begin{tabular}{lrl}
\hline $\mathrm{pH}$ & 8.1 \\
Alkalinity & $11000 \mathrm{mg} \mathrm{L}^{-1}$ & as $\mathrm{CaCO}_{3}$ \\
Total hardness & $2100 \mathrm{mg} \mathrm{L}^{-1}$ & as $\mathrm{CaCO}_{3}$ \\
$\mathrm{Ca}^{2+}$ & $520 \mathrm{mg} \mathrm{L}^{-1}$ & \\
$\mathrm{Mg}^{2+}$ & $195 \mathrm{mg} \mathrm{L}^{-1}$ \\
Organic nitrogen $^{-1}$ & $40 \mathrm{mg} \mathrm{L}^{-1}$ \\
$\mathrm{NH}_{4}^{+}$ & $680 \mathrm{mg} \mathrm{L}^{-1}$ \\
TOC & $10000 \mathrm{mg} \mathrm{L}^{-1}$ \\
Specific organic compound analysis & \\
Phenol & $15000 \mu \mathrm{g} \mathrm{L}^{-1}$ \\
2-Methylphenol & $1400 \mu \mathrm{g} \mathrm{L}^{-1}$ \\
4-Methylphenol & $2500 \mu \mathrm{g} \mathrm{L}^{-1}$ \\
2,4-Dimethylphenol & $300 \mu \mathrm{g} \mathrm{L}^{-1}$ \\
4-Chloro-3-Methylphenol & $1400 \mu \mathrm{g} \mathrm{L}^{-1}$ \\
Bis (2-Ethylhexyl) Phthalate & $20 \mu \mathrm{g} \mathrm{L}^{-1}$ \\
Benzoic acid & $2500 \mu \mathrm{g} \mathrm{L}^{-1}$ \\
3,3'-Dichlorobenzidine & $120 \mu \mathrm{g} \mathrm{L}^{-1}$ \\
Benzo (k) fluoranthene, or & $20 \mu \mathrm{g} \mathrm{L}^{-1}$ \\
$\quad$ Benzo (a) Pyrene & $25 \mu \mathrm{g} \mathrm{L}^{-1}$ \\
$\quad$ (Indistinguishable) & \\
\hline
\end{tabular}

relatively low organic content of the municipal leachate; i.e., $58 \mathrm{mg} \mathrm{L}^{-1}$ as TOC. This value is considerably less than those reported for other leachates derived all or in part from municipal wastes (Chian and Dewalle, 1977; Gourdon et al., 1989, Harmsen, 1983). One contributing factor may be that a portion of the cell from which the sample was extracted was still activate at the time of sampling. The lack of a finished drainage cover over the cell, coupled with the fact that the leachate was collected following a rainy period, may implicate dilution as a potential explanation for the lower than expected TOC concentration. A sample collected several months earlier from another drain at the same landfill had a TOC content of $120 \mathrm{mg} \mathrm{L}^{-1}$, approximately twice that of the test sample.

Gas chromatography-mass spectroscopy analysis focused on the identification of organic compounds on the U.S. EPA priority pollutants list. In both cases, the proportion of TOC specifically identified was very small; less than ten percent and one percent for the municipal and industrial leachates, respectively. Diethylphthalate was the principle priority organic detected in the municipal leachate, along with lesser mass concentrations of other phthalate derivatives. These are likely extracted from plastics and other synthetic organics commonly present in municipal solid wastes. Several free fatty acids were also identified. Conversely, phenolic compounds comprised nearly $90 \%$ of the identifiable TOC in the industrial leachate. Phenol itself was the primary component, followed by several methylphenol derivatives. Benzoic acid was also detected at significant levels.

The composition of the unidentified TOC is speculative given the sparsity of available data. The visual appearance of the leachates evidenced the presence of 
TABLE III

Molecular weight distribution of the two leachates prior and subsequent to adsorption

\begin{tabular}{|c|c|c|c|c|}
\hline & & \multirow[b]{2}{*}{ Total } & \multicolumn{2}{|c|}{ Molecular weight range } \\
\hline & & & $<3000$ & $>70.000$ \\
\hline \multicolumn{5}{|c|}{ Municipal landfill leachate } \\
\hline \multirow[t]{2}{*}{ Before adsorption } & $\operatorname{TOC}\left(\mathrm{mg} \mathrm{L}^{-1}\right)$ & 26.4 & 23.4 & 1.0 \\
\hline & $\%$ TOC & & 96 & 4 \\
\hline \multirow[t]{2}{*}{ After adsorption } & TOC $\left(\mathrm{mg} \mathrm{L}^{-1}\right)$ & 17.5 & 15.4 & 0.7 \\
\hline & $\% \mathrm{TOC}$ & & 96 & 4 \\
\hline \multicolumn{5}{|c|}{ Industrial landfill leachate } \\
\hline \multirow{2}{*}{ Before adsorption } & TOC $\left(\mathrm{mg} \mathrm{L}^{-1}\right)$ & 61.8 & 53.6 & 6.6 \\
\hline & $\%$ TOC & & 89 & 11 \\
\hline \multirow[t]{2}{*}{ After adsorption } & $\operatorname{TOC}\left(\mathrm{mg} \mathrm{L}^{-1}\right)$ & 41.6 & 32.7 & 5.4 \\
\hline & $\%$ ТОС & & 86 & 14 \\
\hline
\end{tabular}

substantial quantities of humic and fulvic material. Gel permeation chromatography analyses, the results of which are given in Table III, lend some additional insight. Both leachates were similar in that they exhibited two distinct molecular weight groupings of less than 3000 and greater than 70000 . In the municipal leachate, the high molecular weight fraction was very small, in the order of $4 \%$, and had a molecular weight in the range of 85000 to 90000 based upon the protein standard curves for the G-100 column. The elution volume of the largest portion of the low molecular weight fraction in the G-50 column indicates a molecular weight of substantially less than 1500 for $81 \%$ of the total TOC, while a small peak comprising approximately $15 \%$ of the total TOC eluted at a volume corresponding to 2500 on the standard calibration curve. The low molecular weight fraction of the industrial leachate appeared as one broad peak centered at a molecular weight of 2000 , and comprises nearly $90 \%$ of the total TOC of the untreated mixture. The larger molecules were in the size range of 75000 to 85000 according to their elution volume. The percent TOC values for the molecular weight fractions, given in Table III, are calculated on the basis of the sum of the TOCs for the individual fractions. This sum is less than the total TOC value of the sample before concentration and subsequent molecular weight separation, the resulting losses having been noted previously in the experimental section.

These results correspond closely to several previous studies conducted with municipal and industrial leachates. In one instance involving a high strength leachate (TOC $>17000 \mathrm{mg} \mathrm{L}^{-1}$ ), nearly $92 \%$ of the TOC was represented by compounds with molecular weights less than 1000 , while $6 \%$ of the mixture was in a range greater than 30000 to 50000 (Chian, 1977). Analysis of a lower strength waste (TOC $\sim 650 \mathrm{mg} \mathrm{L}^{-1}$ ) in the same study revealed that virtually all of the TOC was comprised of refractory compounds of molecular weights less than 10000 , with $94 \%$ determined to be less than 500 . In a different study, more than $95 \%$ of the 
TOC of a leachate derived largely from industrial wastes was found to consist of compounds with molecular weights less than 500 , while the fraction greater than 20000 was only $1.45 \%$ (Gourdon et al., 1989). A similar result was found in a third investigation involving municipal leachate from a landfill in the so-called acidification stage (Harmsen, 1983). However, leachate from a more aged portion of the same landfill, a portion considered to be in the fermentation stage, had a less-than-1000 molecular weight fraction of just $12 \%$ of the total TOC, $20 \%$ in the 1000 to 50000 range, and the remaining $68 \%$ greater than 50000 (ibid.). These results serve as a reminder of the locally specific nature of landfill leachates, and of the need for precharacterization studies to determine what are likely to be the more effective treatment scheme to investigate further for particular wastes.

Table III also indicates that the molecular weight distribution is not altered appreciably after the leachates undergo treatment by activated $\mathrm{C}$ adsorption sufficient to remove approximately $35 \%$ of the original TOC. Naturally, the larger absolute removals are from the low molecular weight fractions. Even the smaller peak that could be discriminated in the municipal leachate (MW $\sim 2500$ ) represented just greater than $15 \%$ of the original TOC, the same value as in the untreated sample. For the industrial leachate, a slightly greater proportion of the lower molecular weight fraction was removed by adsorption, as evidenced by the percentages for the remaining fraction, although, arguably, the difference may be negligible.

\section{ADSORPTIVE CHARACTERISTICS - EQUILIBRIA}

Descriptive modeling of the adsorption behavior of relatively uncharacterized, complex, organic mixtures has frequently been done using a single lumped parameter such as TOC or dissolved organic carbon (DOC). The single-solute scheme is easy to implement, provides a relatively rapid means for quantifying the overall adsorptive characteristics of complex mixtures, and can, in certain cases, yield reasonable description, and even prediction, of adsorption data. This approach has been applied for multicomponent adsorption of synthetic organics (Endicott and Weber, 1985), for adsorption of naturally-occurring organic material such as humic and fulvic acids (Lee et al., 1981), and for systems comprised of both synthetic organics and natural organic matter (Smith et al., 1987; Clark, 1987). Landfill leachates are best simulated as the latter type of system; that is, as a mixture containing both specifically targeted organic compounds and natural background organic matter.

In this study, TOC was used as the lumped concentration parameter for organics. Log-log plots of liquid-phase versus solid-phase concentration data from isotherm experiments are shown in Figures 1 and 2 for municipal and industrial leachates, respectively. In each case, data were obtained for two initial TOC concentrations. The solid lines represent model curves according to the Freundlich isotherm equation:

$$
Q_{e}=K_{F} C_{e}^{n},
$$

where $Q_{e}$ and $C_{e}$ are the solid- and liquid-phase concentrations of leachate in $(\mathrm{mg}$ TOC $\mathrm{g}^{-1} \mathrm{C}$ ) and (mg TOC L $\left.{ }^{-1}\right)$, respectively; and $K_{F}$ and $n$ are characteristic constants 


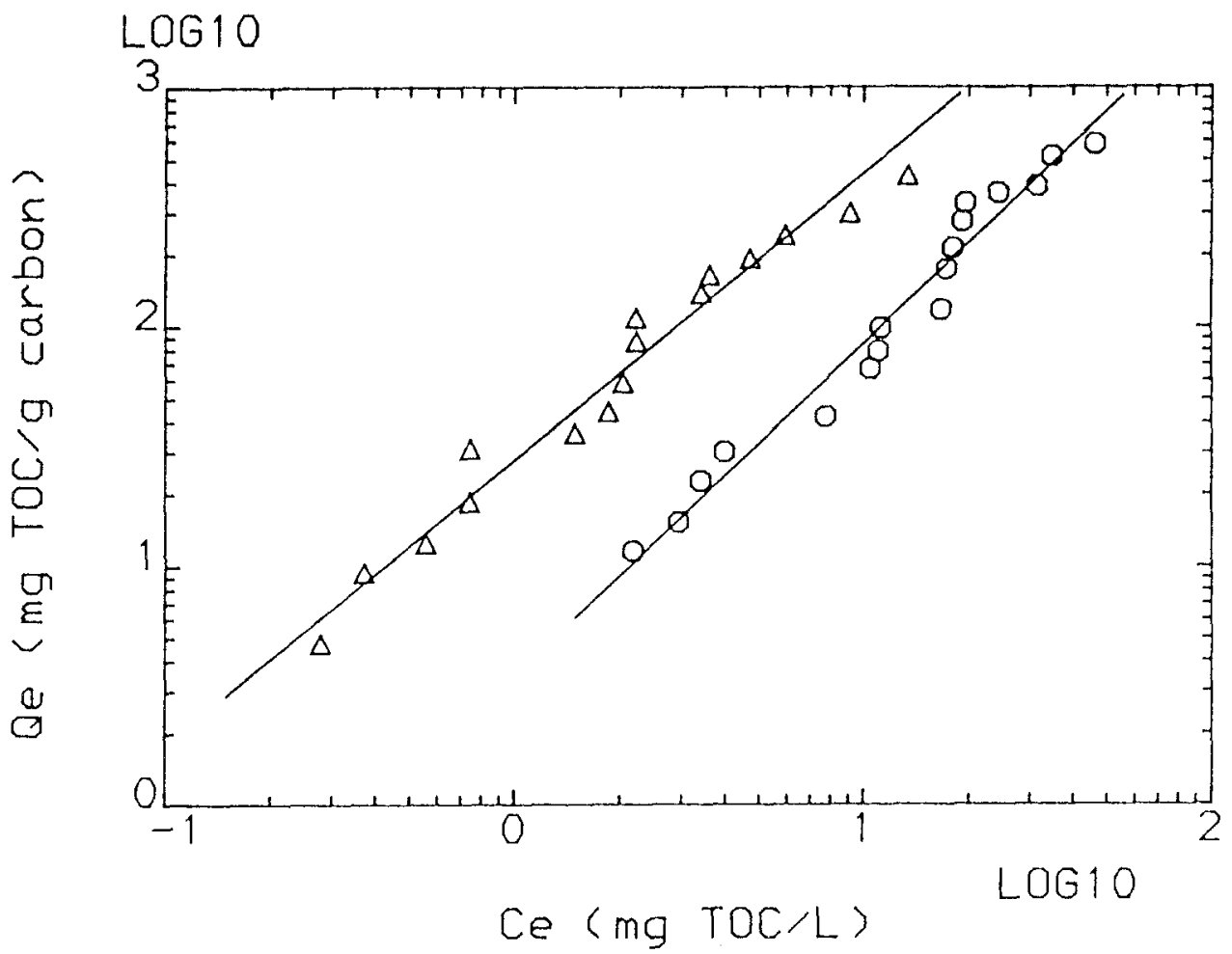

Fig. 1. Isotherm data and Freundlich model traces for municipal landfill leachate. $\left(\Delta-C_{O} \sim 25 \mathrm{mg}\right.$ $\mathrm{TOC} / \mathrm{L} ;(\mathrm{O})-\mathrm{C}_{\mathrm{O}} \sim 60 \mathrm{mg} \mathrm{TOC} / \mathrm{L}$.

evaluated by multiple linear regression of the isotherm data. Freundlich isotherm coefficients and their corresponding 95\% confidence limits are given in Table IV.

Both leachate samples exhibit a phenomenon typical of adsorption isotherms conducted in multiple CMBR systems using different initial concentrations of organic

\section{TABLE IV}

Freundlich isotherm coefficients for two leachates modeled as single component solutions

\begin{tabular}{|c|c|c|c|c|c|c|}
\hline & $\begin{array}{l}\mathrm{C}_{\mathrm{O}} \\
\left(\mathrm{mg} \mathrm{L}^{-1} \text { as } \mathrm{TOC}\right)\end{array}$ & $\mathrm{K}_{\mathrm{F}}$ & $\begin{array}{l}95 \% \\
\text { Confidence } \\
\text { interval }\end{array}$ & $n$ & $\begin{array}{l}95 \% \\
\text { Confidence } \\
\text { interval }\end{array}$ & $r^{2}$ \\
\hline $\begin{array}{l}\text { Municipal landfill } \\
\text { leachate }\end{array}$ & $\begin{array}{l}25 \\
60 \\
\text { Normalized } \\
\text { isotherm }\end{array}$ & $\begin{array}{r}28.0 \\
3.5 \\
23.1\end{array}$ & $\begin{array}{r}23.9-32.9 \\
2.4-5.1 \\
20.5-25.9\end{array}$ & $\begin{array}{l}1.20 \\
1.39 \\
0.49\end{array}$ & $\begin{array}{l}1.07-1.33 \\
1.25-1.53 \\
0.46-0.52\end{array}$ & $\begin{array}{l}0.966 \\
0.966 \\
0.972\end{array}$ \\
\hline $\begin{array}{l}\text { Industrial landfill } \\
\text { leachate }\end{array}$ & $\begin{array}{l}16 \\
60 \\
\text { Normalized } \\
\text { isotherm }\end{array}$ & $\begin{array}{r}59.9 \\
5.9 \\
26.0\end{array}$ & $\begin{array}{r}42.3-84.7 \\
3.5-9.9 \\
22.9-29.4\end{array}$ & $\begin{array}{l}1.07 \\
1.44 \\
0.51\end{array}$ & $\begin{array}{l}0.81-1.33 \\
1.21-1.66 \\
0.48-0.54\end{array}$ & $\begin{array}{l}0.914 \\
0.945 \\
0.982\end{array}$ \\
\hline
\end{tabular}




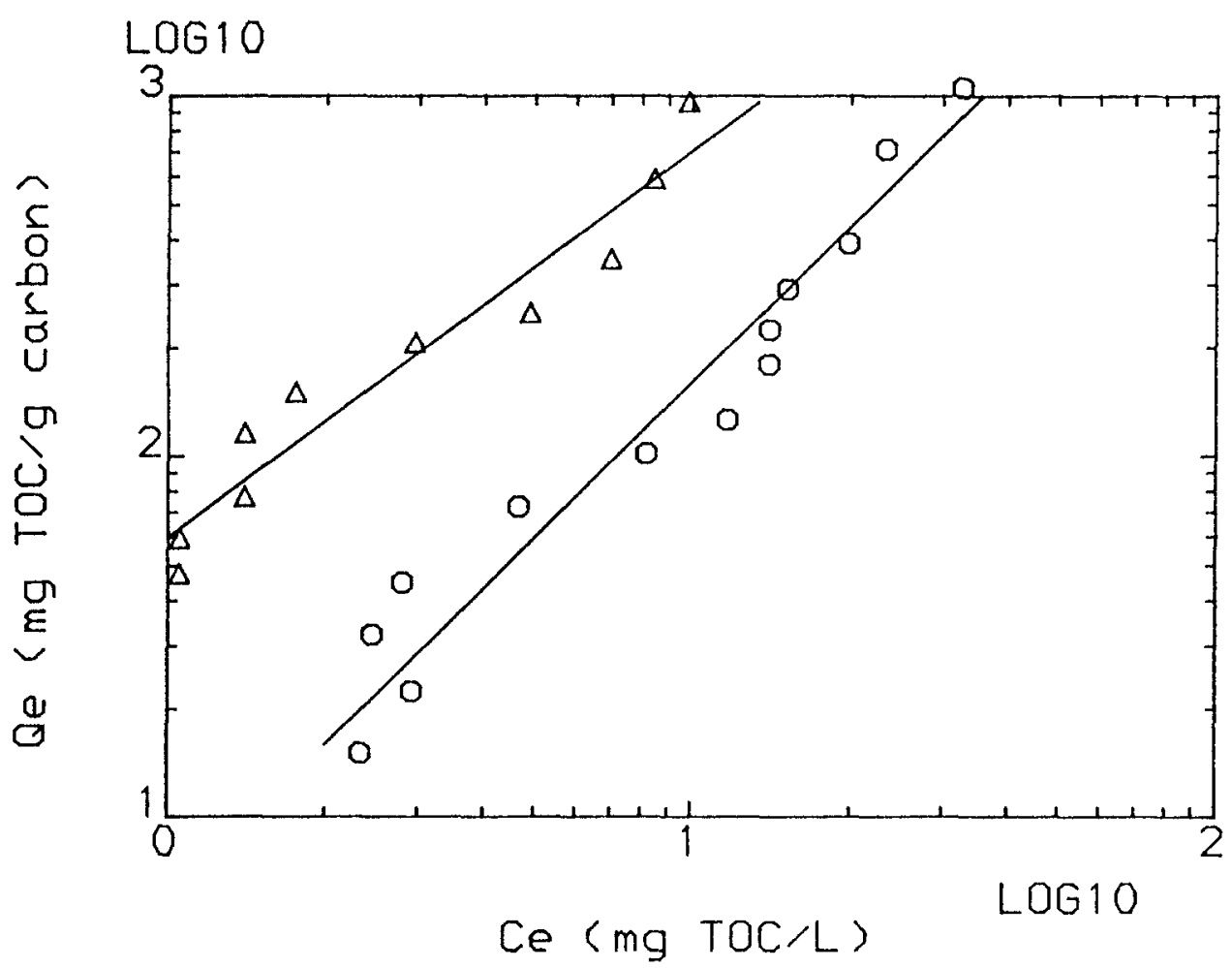

Fig. 2. Isotherm data and Freundlich model traces for industrial landfill leachate. $(\Delta)-\mathrm{C}_{\mathrm{O}} \sim 16 \mathrm{mg}$ $\mathrm{TOC} / \mathrm{L} ;(\mathrm{O})-\mathrm{C}_{\mathrm{O}} \sim 60 \mathrm{mg}$ TOC $/ \mathrm{L}$.

matter and overlapping sets of adsorbent dosages; namely, an apparent dependence of adsorption capacity at any residual solution phase concentration on the initial TOC concentration. This is particularly true for $\mathrm{C}$ adsorption of natural organic matter such as humic and/or fulvic substances, and is indicative of both the heterodisperse nature of the organic substrate and the heterogeneous nature of adsorption sites on the adsorbent. In such cases the resulting data can be normalized by adjusting for the dosage of adsorbant used to achieve a certain residual concentration; that is by relating sorption capacity to the ratio of the residual concentration of solute to the dosage employed in a particular CMBR system. The resulting normalized Freundlich equation has the form:

$$
Q_{c}=K_{F}\left(C_{e} / D\right)^{n}=K_{F} C_{N}^{n} \text {. }
$$

where $D$ is the adsorbent dosage (mass of adsorbent added per liquid volume of reactor contents) resulting in the normalized liquid-phase concentration, $C_{N}=C_{c} / D$,

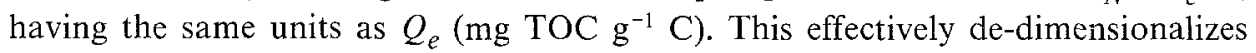
the exponent $n$, which is a measure of adsorption intensity. The Freundlich parameters for the normalized isotherms are presented in Table IV, and the respective plots of the normalized data and model curves are shown in Figures 3 and 4 for the 


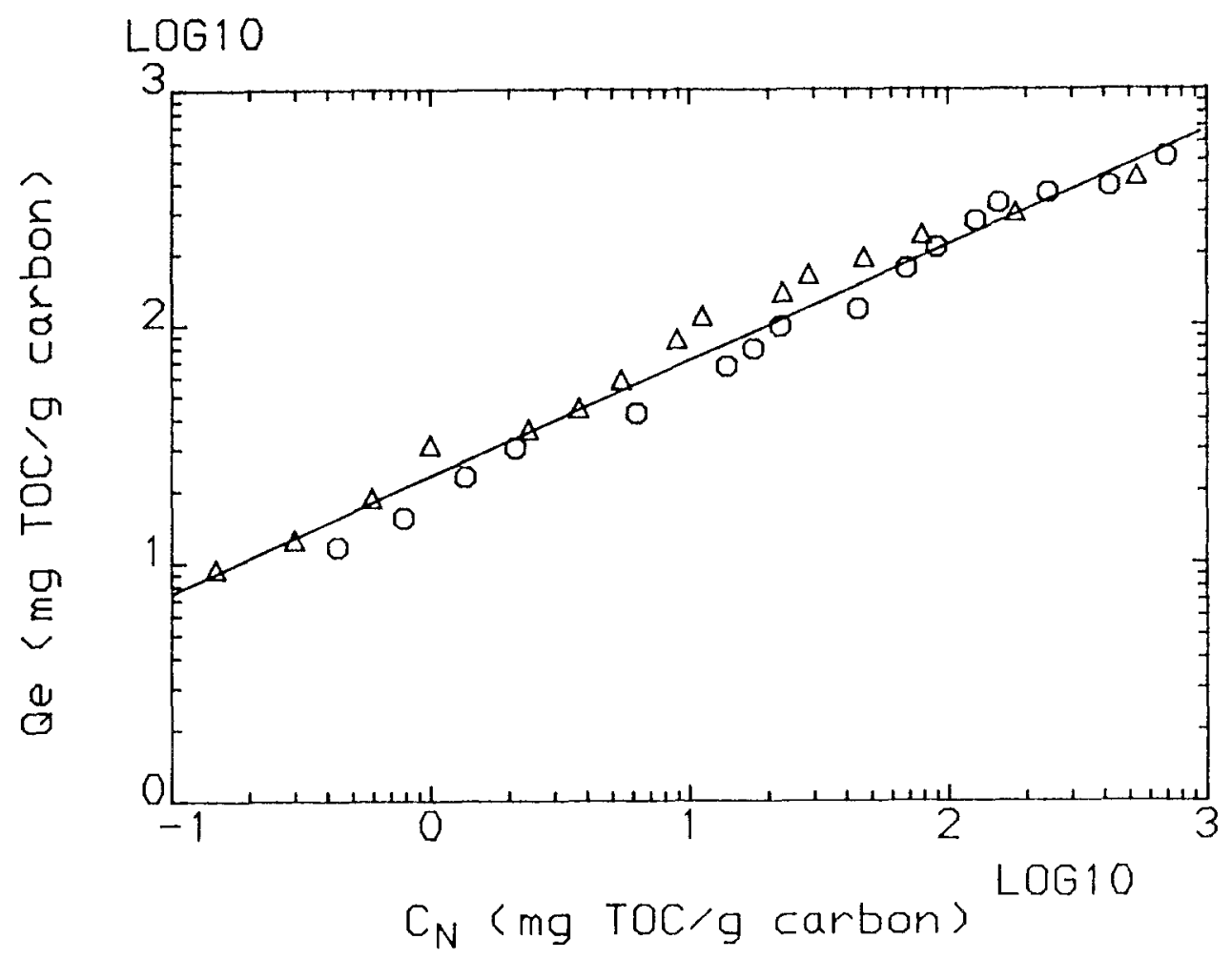

Fig. 3. Normalized Freundlich isotherm for municipal landfill leachate. $(\Delta)-$ data for $C_{O}=25 \mathrm{mg}$ $\mathrm{TOC} / \mathrm{L} ;(\mathrm{O})$ - data for $\mathrm{C}_{\mathrm{O}}=60 \mathrm{mg} \mathrm{TOC} / \mathrm{L}$.

municipal and landfill leachates. The figures illustrate a fairly good fit to a single isotherm expression, consistent with observations by other investigators (Summers and Roberts, 1988). Values of the correlation parameter, $r^{2}$, in Table IV are higher for the normalized isotherms than for either of the two independent isotherms for a given leachate. In addition, the confidence bands for the coefficients are significantly narrower for the normalized equation (on a percent basis). Interestingly, the normalized expressions for the two leachates are nearly identical. In fact, the coefficients for the two leachates for the like case of initial TOC $=60 \mathrm{mg} \mathrm{L}^{-1}$ are also similar, with appreciable overlap of the $95 \%$ confidence intervals. Even for the case of lower (and different) initial TOCs, the parameter values for the two leachate are not so variant, given the evident trend of increasing $K_{F}$ and decreasing $\mathrm{n}$ with decreasing initial concentration. That the equilibria of the two leachates are so proximate when normalized is a somewhat unanticipated result, given alleged differences in the natures of the wastes deposited in the respective landfills. This finding may relate to the similarity also apparent in the molecular weight distributions for these two leachates.

It must be born in mind that the above comparisons pre-suppose that the system is mono-component, an assumption contradicted in part, as noted, by the significant 


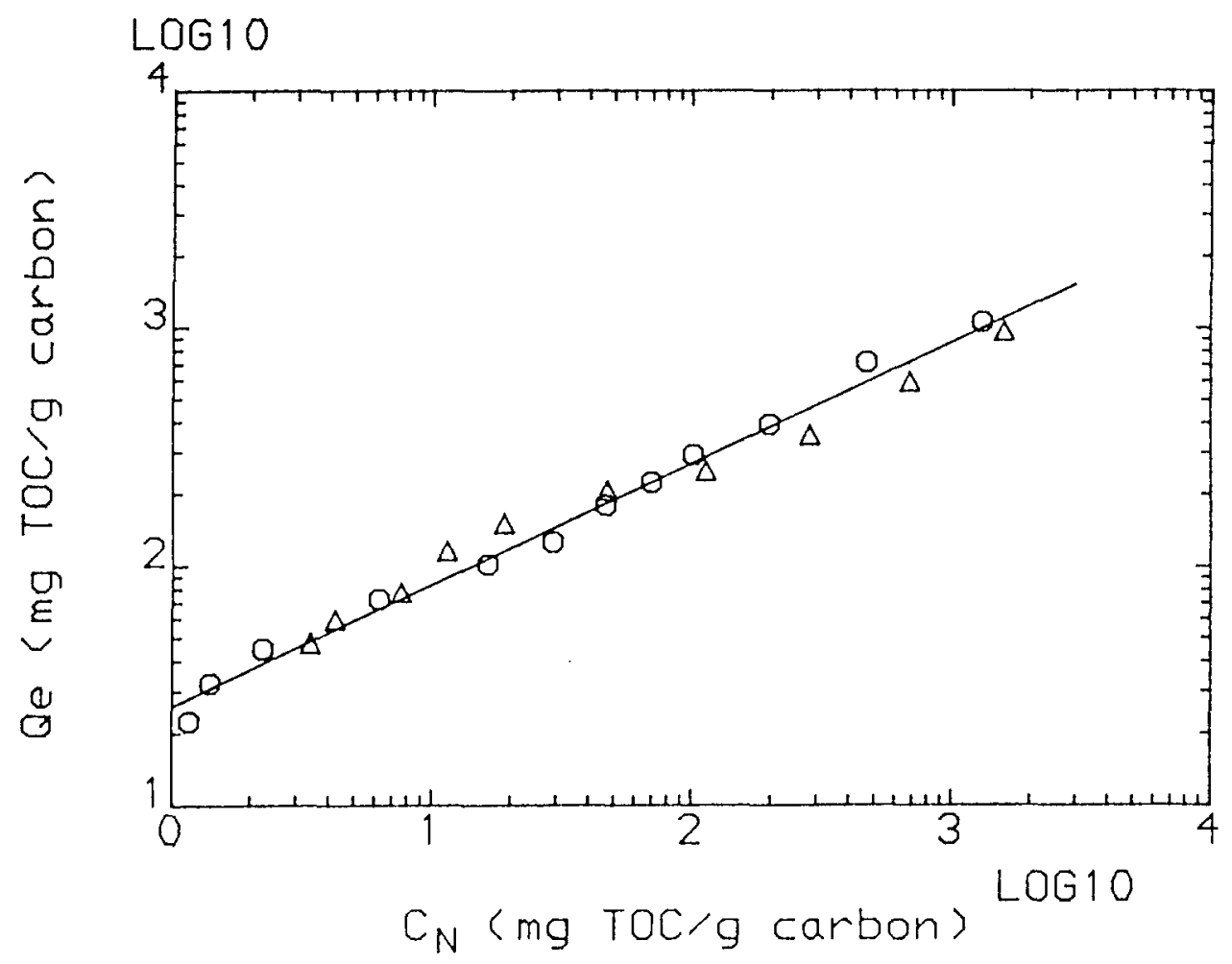

Fig. 4. Normalized Freundlich isotherm for industrial landfill leachate. $(\Delta)-$ data for $C_{O}=16 \mathrm{mg}$ $\mathrm{TOC} / \mathrm{L} ;(\mathrm{O})$ - data for $\mathrm{C}_{\mathrm{O}}=60 \mathrm{mg} \mathrm{TOC} / \mathrm{L}$.

dependence of the adsorption isotherm on initial concentration. The shapes of the $\log -\log$ plots of equilibrium data, especially for the industrial leachate, are also characteristic of those reported for other natural dissolved organic matter, and indicative of multiple solute systems. In such systems, isotherms change shape in response to changes in $\mathrm{C}$ concentration, because of resulting changes in the proportions of different solutes in each phase (Weber et al., 1983; Weber and Jodellah, 1985). In Figure 2, for example points in the highest liquid-phase equilibrium concentration region yield a relatively steep 'local' slope. These points correspond to the smallest $\mathrm{C}$ doses, and to removal of only the most adsorbable of species from solution. For increasing $\mathrm{C}$ dosages, the adsorption capacity is not fully utilized by the highly adsorbable fraction, resulting in a decreased local slope corresponding to uptake of less adsorbable species. Finally, the lower portion of the isotherm corresponds to the highest $\mathrm{C}$ doses, and in some instances approaches a nearly vertical local slope, indicative of a substantially nonadsorbable organic fraction.

With these considerations in mind, multicomponent modeling of adsorption equilibria for the industrial leachate was applied. This approach was chosen for the industrial leachate because its adsorption behavior did not conform as closely to the Freundlich model as did that of the municipal leachate, as reflected in the 
lower values of $\mathrm{r}^{2}$ and the wider confidence bands for the coefficients determined for the industrial leachate. The ideal adsorbed solution theory (IAST) model was employed, and the solution TOC content distributed among three 'imaginary' components, one nonadsorbable and two adsorbable. The number of adsorbable components was limited to two to maintain simplicity; moreover, the particular dynamic model used also has this limitation. Detailed development, assumption, and limitations of the IAST model for systems that include uncharacterized organic matter are given elsewhere (Frick and Sontheimer, 1983; Crittenden et al., 1985; Fettig and Sontheimer, 1987a; Harrington and DiGiano, 1989). The basic equations to be solved are of the form:

$$
C_{o, i}-Q_{i} D=\frac{Q_{i}}{\sum_{j=1}^{N} Q_{j}}\left[\frac{\sum_{j=1}^{N} Q_{j} \gamma_{j}}{\gamma_{i} K_{F, i}}\right]^{\gamma_{i}}
$$

for $i=1$ to $N$, where $N$ is the number of adsorbable imaginary components, $\gamma$ is the inverse of the Freundlich exponent $n, C_{0, i}$ is the initial TOC of $i$, and Equation (1) is used to characterize single-solute adsorption equilibria. A Newton-Raphson algorithm was implemented to search values for $C_{o, i}, K_{F, i}$, and $\gamma_{i}$ (or $\mathrm{n}_{i}$ ) that minimize the deviation between experimental and calculated values of the equilibrium liquid-phase concentration. Because IAST is based upon molar concentrations of the components, the model as applied here assumes that the imaginary components each have the same molecular weight with respect to $\mathrm{C}$. Table $\mathrm{V}$ gives a summary of 'searched values' of IAST model parameters for the industrial landfill leachate at two initial concentrations. The nonadsorbable component was considered to comprise $4 \%$ of the TOC in both simulations, a consensus value derived from visual inspection and a linear approximation of the data (Kaastrup et al., 1985). The solid lines in Figure 5 illustrate the fit of the model to experimental data for the two cases considered.

If IAST, as applied, provides a correct description of the adsorption equilibria for a given system, then the searched parameters should be approximately the same for varying initial TOC concentrations, the only difference being the absolute values

TABLE V

IAST model parameters for industrial landfill leachate

\begin{tabular}{|c|c|c|c|c|c|c|c|}
\hline \multirow{2}{*}{$\begin{array}{l}\mathrm{C}_{\mathrm{OT}} \\
\left(\mathrm{mg} \mathrm{L} \mathrm{L}^{-1} \text { as } \mathrm{TOC}\right)\end{array}$} & \multicolumn{3}{|c|}{$\begin{array}{l}\text { Hypothetical } \\
\text { component } 1\end{array}$} & \multicolumn{3}{|c|}{$\begin{array}{l}\text { Hypothetical } \\
\text { component } 2\end{array}$} & \multirow{2}{*}{$\begin{array}{l}\text { Nonadsorbing } \\
\text { component } \\
\left(\% \mathrm{C}_{\mathrm{OT}}\right)\end{array}$} \\
\hline & $K_{F}$ & $n$ & $\% \mathrm{C}_{\mathrm{OT}}$ & $K_{F}$ & $n$ & $\% \mathrm{C}_{\mathrm{OT}}$ & \\
\hline 16 & 251 & 0.87 & 66 & 75 & 0.14 & 30 & 4 \\
\hline 60 & 104 & 0.77 & 79 & 16 & 0.20 & 17 & 4 \\
\hline
\end{tabular}




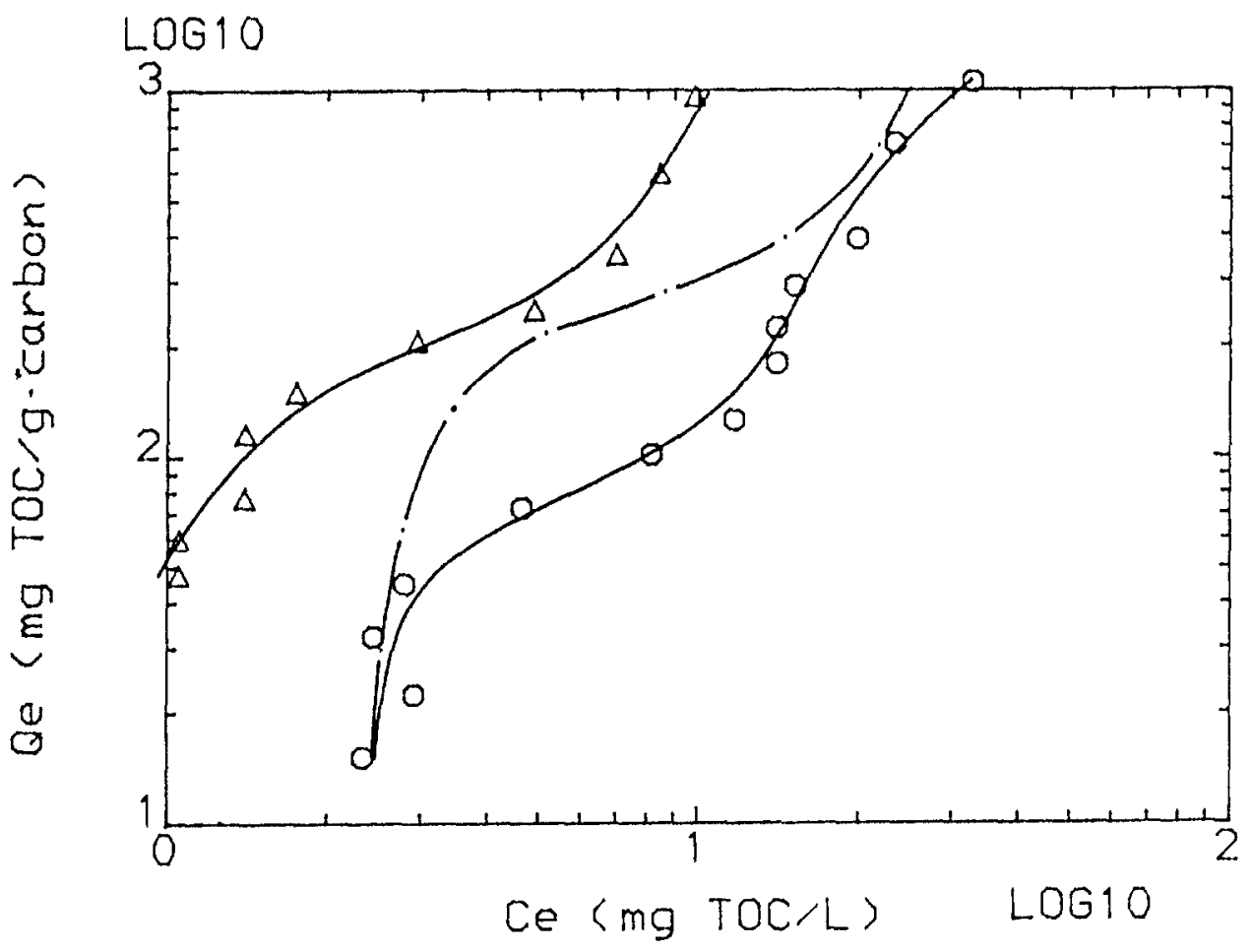

Fig. 5. Multicomponent modeling of industrial landfill leachate equilibrium data by IAST $(\Delta)-\mathrm{C}_{\mathrm{O}}$ $=16 \mathrm{mg} \mathrm{TOC} / \mathrm{L} ;(\mathrm{O})-\mathrm{C}_{\mathrm{O}}=60 \mathrm{mg} \mathrm{TOC} / \mathrm{L}$. Solid lines represent best fit of data. Broken line is prediction of $C_{O}(60)$ equilibria using best fit parameters for $C_{O}(16)$.

of $C_{o, i}$ for the imaginary components. It is apparent from Table $V$ that this is not the case. The broken line in Figure $V$ is the predicted model curve for $\mathrm{C}_{\mathrm{OT}}=60$ $\mathrm{mg} \mathrm{L}^{-1}$ using IAST parameters searched for $\mathrm{C}_{\mathrm{OT}}=16 \mathrm{mg} \mathrm{L}^{-1}$. These values overpredict the solid-phase loading for the concentration range of interest. A similarly poor estimate was observed when $\mathrm{C}_{\mathrm{OT}}(60)$ parameters were used to predict $\mathrm{C}_{\mathrm{OT}}$ (16) equilibria, except in this case the solid phase loading was underpredicted. Although values of the Freundlich exponent and $\% \mathrm{C}_{\mathrm{OT}}$ for the respective imaginary components are not widely variant in terms of absolute quantities, the $K_{F}$ values are as much as five times greater for a total initial TOC of $16 \mathrm{mg} \mathrm{L}^{-1}$. The significant deviation is likely indicative of the need to assume additional imaginary components to simulate the mixture behavior more adequately. Nevertheless, the technique as applied here provided a better fit of the isotherm data than did a single solute Freundlich model, reducing the errors between model and experimental points to 20 to $40 \%$ of those for the single-solute model.

ADSORPTIVE CHARACTERISTICS - RATES

Concentration - time data from CMBR experiments are illustrated for the two leachates in Figures 6 and 7. Description of the rate profile was attempted using 


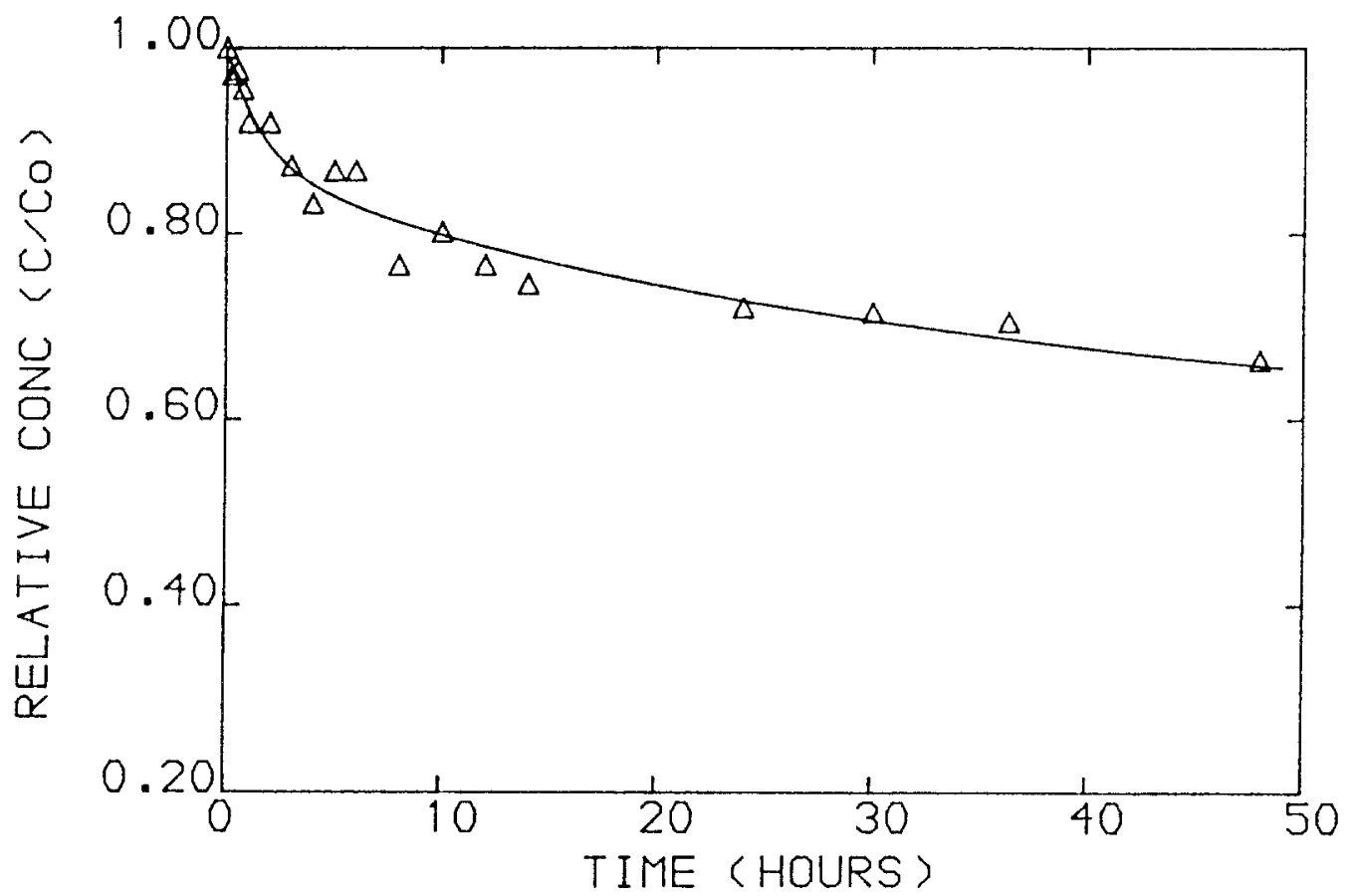

Fig. 6. CMBR rate data and model simulation of municipal landfill leachate as a single component system.

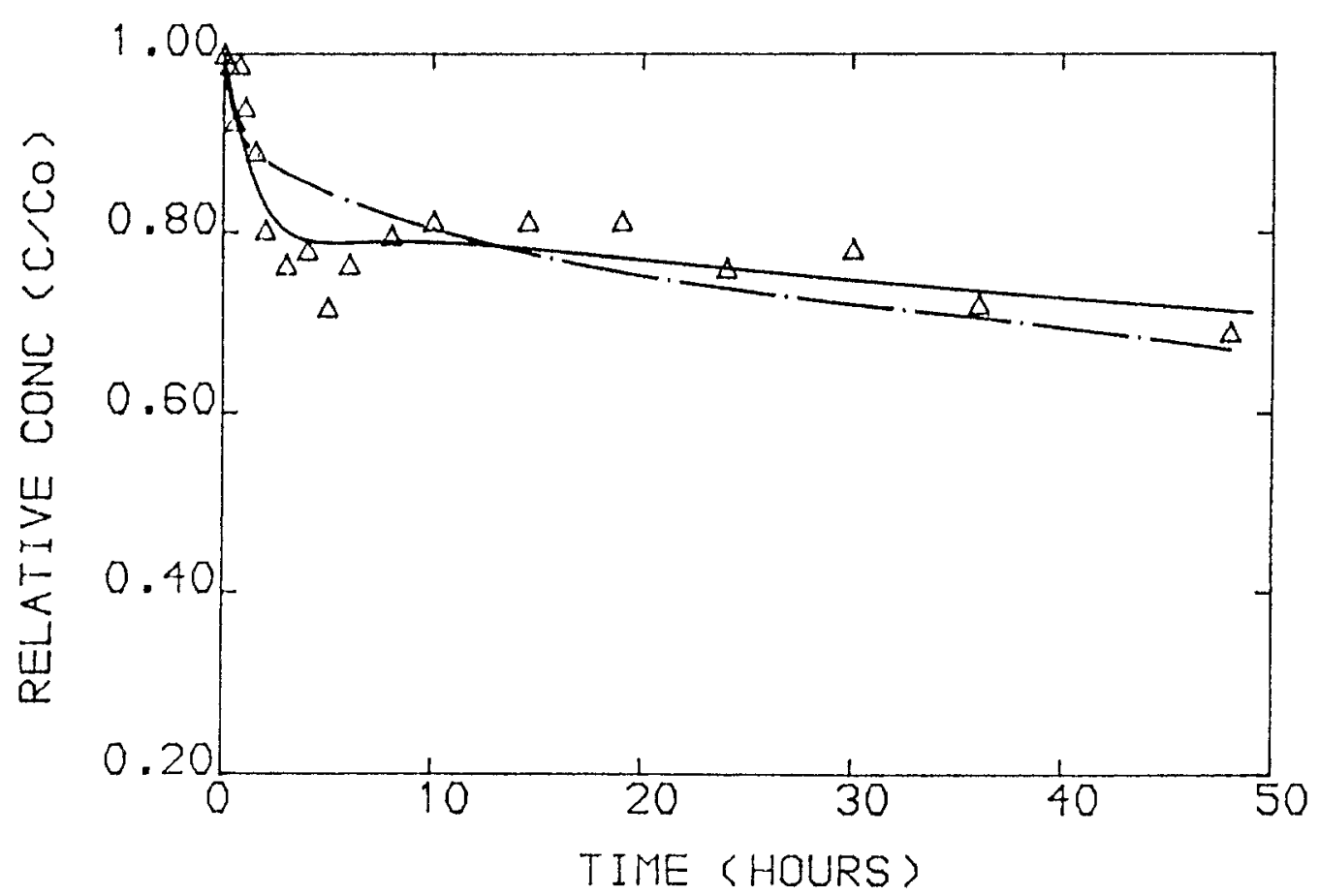

Fig. 7. CMBR rate data and model simulation of industrial landfill leachate. Broken line represents single-solute modeling approach. Solid line is multi-component model description using IAST equilibrium parameters. 
a CMBR-mode homogeneous surface diffusion (HSD) model in which the appropriate liquid- and solid-phase material balance expressions and accompanying initial and boundary conditions are solved numerically. The model utilizes an appropriate equilibrium relationship and considers surface diffusion as the controlling intraparticle mass transport mehanism, in series with external or film mass transfer. Mathematical development of the model for CMBR systems is detailed elsewhere (Hand et al., 1983; Mathews and Weber, 1984).

In Figure 6, municipal leachate data are described according to a single-solute version of the HSD model, using TOC content to represent the mixture as a single component. The model applied in this fashion provides a reasonably good fit of the data, at least for the initial $48 \mathrm{hr}$ of reaction. Corresponding values of the film and surface diffusion coefficients $\mathrm{k}_{\mathrm{f}}$ and $\mathrm{D}_{\mathrm{s}}$, which are searched from the data using the model and an error minimization function, are listed in Table VI. As for single-solute equilibrium parameters, single-solute batch rate coefficients were found to be of the same order of magnitude for similar initial TOC concentrations.

Figure 7 shows rate data and model simulations for the industrial leachate. The single solute model, depicted by the broken line, does not describe the experimental data nearly as well here as it did in the case of the municipal leachate. The solid line represents an attempt to more accurately describe the data using a multicomponent version of the rate model and imaginary components, with the corresponding equilibrium and concentration parameters calculated previously using IAST. The rate data profile for the industrial leachate shows a rapid removal of TOC during the initial hour of adsorption, followed by a small increase before assuming a slow, but steady rate of TOC removal in the latter stages of the process. This pattern resembles the competitive displacement of more rapidly diffusing components by more strongly adsorbed compounds commonly observed in fixed-bed adsorber studies (Thacker et al., 1984; Smith and Weber, 1988). Obviously, the single-solute model does not simulate competitive effects, whereas these impacts are captured to some degree by the multicomponent version. Using a two-component dynamic model for the imaginary components (the analysis must also include the nonadsorbable fraction), the error between calculated and experimental values was reduced by $40 \%$. That the fit in the displacement region is still not precise may be further indication of the need to consider additional imaginary components for more accurate characterization of mixture behavior.

\section{TABLE VI}

CMBR rate parameters for leachates modeled as single component solutions

\begin{tabular}{llll}
\hline & $\begin{array}{l}\mathrm{C}_{\mathrm{O}} \\
\left(\mathrm{mg} \mathrm{L}^{-1} \text { as TOC }\right)\end{array}$ & $\begin{array}{l}k_{f} \\
\left(\mathrm{~cm} \mathrm{~s}^{-1} \times 10^{3}\right)\end{array}$ & $\begin{array}{l}D_{s} \\
\left(\mathrm{~cm}^{2} \mathrm{~s}^{-1} \times 10^{11}\right)\end{array}$ \\
\hline Municipal leachate & 60 & 6.7 & 22.5 \\
Industrial leachate & 60 & 9.5 & 18.0 \\
\hline
\end{tabular}


TABLE VII

CMBR rate parameters for industrial landfill leachate modeled as a multicomponent solution $\left(\mathrm{C}_{\mathrm{OT}}=60 \mathrm{mg} \mathrm{L}^{-1}\right)$

\begin{tabular}{llll}
\hline $\begin{array}{l}\text { Imaginary } \\
\text { component }\end{array}$ & $\% \mathrm{C}_{\mathrm{OT}}$ & $\begin{array}{l}k_{f: b} \\
\left(\mathrm{~cm} \mathrm{~s}^{-1} \times 10^{3}\right)\end{array}$ & $\begin{array}{l}D_{s} \\
\left(\mathrm{~cm}^{2} \times 10^{11}\right)\end{array}$ \\
\hline 1 & 79 & 6.2 & 2.2 \\
2 & 17 & 21.0 & 2.2 \\
\hline
\end{tabular}

Model runs using the normalized equilibrium expression yield essentially the same result as the single-component analysis. This approach also suffers from its inability to account for competition among components in the mixture (Harrington and DiGiano, 1989).

CMBR rate parameters for the multicomponent analysis are given in Table VII. The CMBR film transfer coefficients determined from best-fit searches vary considerably for the two components, with the more weakly adsorbed component having a value more than three times greater than that for the strongly adsorbed imaginary compound. This differs from the conclusions derived from a previous study of a fulvic acid using the IAST-pseudo-component approach, where a minicolumn method yielded external mass transfer coefficients that were essentially equal for the assumed imaginary components (Fettig and Sontheimer, 1987b). The authors of that study note, however, that the result they obtained may not be a general observation for other complex mixtures (Ibid). The finding that equal values for the intraparticle diffusion coefficients could be used for each component is a result similar to one observed in the aforementioned study. However, the numerical solution was not very sensitive to the magnitude of $\mathrm{D}_{\mathrm{s}}$ for the weakly adsorbed imaginary component.

The CMBR rate studies also reveal the slow approach to equilibrium that is characteristic of complex mixtures containing significant amounts of natural organic matter. Appreciable removal of TOC is expected well beyond the $48 \mathrm{hr}$ duration of the rate experiments conducted here. The gradual approach to equilibrium makes evaluations of intraparticle mass transfer for such systems a challenging task, since the lengthy time scales involved invite interferences (e.g., biological activity) which can impair attempts to delineate strictly adsorptive mechanisms. Nevertheless, the techniques employed here provide a means for assessing and quantifying the adsorptive characteristics of various waters for bases of comparison. The logical next step would be to utilize the acquired information to design fixed-bed adsorber studies to more thoroughly examine the feasibility and role of carbon adsorption in the handling/ultimate disposal of a particular landfill leachate.

\section{Summary}

Leachates collected from a municipal and an industrial landfill in geographical 
proximity exhibited widely variant chemical compositions. The industrial leachate was a much 'higher strength' waste in terms of both inorganic constituents and organic content, the latter as measured by TOC. Attempts to identify priority organic pollutants in the waste samples revealed the presence of industrial-type compounds, such as phenolics, in the industrial leachate, and phthalate derivatives in the municipal waste, doubtless extracted from plastics and other synthetic materials deposited routinely in the landfill. Various other chemical and adsorptive characteristics of the leachates suggest that humic and/or fulvic materials comprise a measurable portion of the unidentifiable TOC in each case.

Gel permeation studies prior and subsequent to treastment by activated carbon adsorption indicated two distinct molecular weight (MW) fractions for both leachates, the largest fraction having an MW less than 3000, and the smallest fraction (i.e., less than $15 \%$ of the TOC) having an MW greater than 70000 . In the case of the municipal leachate, the small size fraction comprised 96 percent of the TOC, with more than $80 \%$ of this amount having an $\mathrm{MW}<1500$. For the industrial leachate, the $\mathrm{MW}<3000$ fraction comprised 89 and $86 \%$, respectively, of the TOC before and after adsorption.

The two leachates exhibited similar adsorption equilibrium characteristics, at least with respect to Freundlich model coefficients derived from experimental data for solutions having comparable initial TOC concentrations. Statistical deviation from the Freundlich model was greater for the industrial leachate. A multicomponent equilibrium modeling approach utilizing ideal adsorbed solution theory (IAST) and assumptions regarding imaginary components achieved a better fit of the data for this case.

A similar result was observed in completely mixed batch reactor (CMBR) rate experiments. Time-concentration data for the municipal leachate were described reasonably well by a single-solute CMBR version of a homogeneous surface diffusion model. In the case of the industrial leachate, however, there was evidence of competitive interactions among the uncharacterized components in the mixture. These effects were simulated more accurately by a two-component dynamic model using the IAST equilibrium parameters evaluated for the imaginary components. It is likely that even more precise description of the data could be accomplished by inclusion of a larger number of pseudo-components in the analysis.

\section{Acknowledgments}

The authors thank Carol Leedom, Susan Chase, and the Great Lakes Environmental Research Laboratory of the National Oceanic and Atmospheric Administration for performing the GC-MS analysis of leachate samples. Laboratory assistance was provided also by Tracy Arnold and Daniel Peters. This work was supported principally by the U.S. National Science Foundation, Grant CES-8702786, Environmental Engineering Program, Dr. Edward H. Bryan, Program Director. Partial funding to complete certain analyses was subsequently provided by Research Grant 
EDV-041 from Kuwait University, where Dr. Edward Smith was formerly Assistant Professor of Civil Engineering.

\section{References}

Chian, E. S. K.: 1977, Wat. Research 11, 225.

Chian, E. S. K. and Dewalle, F. B.: 1977, Environ. Sci. \& Technol. 11, 158.

Clark, R. M.: 1987, J. Am. Wat. Works Assoc. 79, 33.

Crittenden, J. C., Luft, P. and Hand, D. W.: 1985, Wat. Research 19, 1537.

Endicott, D. D. and Weber, W. J. Jr.: 1985, Environ. Progress 4, 105.

EPA Test Methods: 1982, Methods for Organic Chemical Analysis of Municipal and Industrial Wastewater, Longbottom, J. E. and Lichenberg, J. J. (eds.), U.S. EPA-600/4-82-057.

Fettig, J. and Sontheimer, H.: 1987a, J. Environ. Engin. (ASCE) 113, 780.

Fettig, J. and Sontheimer, H.: 1987b, J. Environ. Engin. (ASCE) 113, 795.

Frick, B. and Sontheimer, H.: 1983, Treatment of Water by Granular Activated Carbon, McGuire, M. J. and Suffet, I. H. (eds.), American Chemical Society, pp. 247-268.

Gourdon, R., Comel, C., Vermande, P. and Veron, J.: 1989, Wat. Research 23, 167.

Hand, D. W., Crittenden, J. C. and Thacker, W. E.: 1983, J. Environ. Engin. (ASCE), 109, 82.

Harmsen, J.: 1983, Wat. Research 17, 699.

Harrington, G. W. and DiGiano, F. A.: 1989, J. Am. Wat. Works Assoc. 81, 93.

Kaastrup, E., Summers, R. S. and Roberts, P. V.: 1985, Proceedings of the 1984 Specialty Conference,

Environ. Engin. Div., in Pirbazari, M., and Devinny, J. S. (ed.), ASCE, New York, pp. 109-117.

Lee, M. C., Snoeyink, V. L. and Crittenden, J. C.: 1981, J. Am. Wat. Works Assoc. 73, 8, 411.

Matthews, A. P. and Weber, W. J., Jr.: 1984, Chem. Eng. Commun. 25, 157.

Peavy, H. S., Rowe, D. R. and Tchobanoglous, G.: 1985, Environmental Engineering. McGraw-Hill, New York, pp. 628-638.

Smith, E. H., Tseng, S. and Weber, W. J. Jr.: 1987, Environ. Progress. 6, 18.

Smith, E. H. and Weber, W. J., Jr.: 1988, Environ. Sci. \& Technol. 22, 313.

Standard Methods for the Examination of Water and Wastewater, 15th Edition: 1980, APHA, AWWA, and WPCF, Washington, D.C.

Summers, R. S. and Roberts, P. V.: 1988, J. Coll. Interface Sci. 122, 367.

Thacker, W. E., Crittenden, J. C. and Snoeyink, V. L.: 1984, J. Wat. Poll. Control Fed. 56, 243.

Weber, W. J., Jr. and Jodellah, A. M.: 1985, J. Am. Wat. Works Assoc. 77, 132.

Weber, W. J., Jr. and Smith, E. H.: 1987, Environ. Sci. \& Technol. 21, 1040.

Weber, W. J., Jr., Voice, T. C. and Jodellah, A. M.: 1983, J. Am. Wat. Works Assoc. 75, 612. 